\title{
電気泳動法によるフグ類の鑑別
}

(昭和 59 年 5 月 24 日受理)

\author{
落合芳博*1 加納碩雄*2 橋本周 久*1
}

\section{Electrophoretic Identification of Puffers}

\author{
Yoshihiro OCHIAI*1, Sekio KANOH*2 and Kanehisa HaSHIMOTO*1 \\ (*1 Laboratory of Marine Biochemistry, Faculty of Agriculture, The University of \\ Tokyo: 1-1-1 Yayoi, Bunkyo-ku, Tokyo, Japan; \\ *2 Tokyo Metropolitan Wholesale Market Sanitation Inspection \\ Station: 5-2-1 Tsukiji, Chuo-ku, Tokyo, Japan)
}

Attempts were made to identify sixteen species of puffers electrophoretically. The myogen fractions were prepared from the ordinary muscle of the puffers, and subjected to polyacrylamide gel electrophoresis. After the runs, the gels were stained for protein with Coomassie brilliant blue, and for some enzymes such as malate dehydrogenase (MDH) and phosphoglucomutase (PGM) with specific reagents. The results obtained showed that the protein patterns are species-specific enough to permit identification of most of the puffers. The MDH and PGM isozyme patterns were less species-specific. The puffers were hardly distinguishable from each other when the myogen fractions were subjected to cellulose acetate membrane electrophoresis. On the other hand, the myogen fractions of most puffers exhibited species-specific protein patterns when subjected to isoelectric focusing, followed by Coomassie brilliant blue staining.

It was concluded from the above results that puffers can be practically identified by the above electrophoretic techniques except cellulose acetate membrane electrophoresis, and that a more reliable identification can be attained by the combined use of these techniques.

(Received May 24, 1984)

Key words: フグ pufferfish; 魚種鑑別 species identification of Fugu; ミオゲン myogen; ポリアクリルアミドゲル電気泳動 polyacrylamide gel electrophoresis; リンゴ酸脱水素酵素 malate dehydrogenase; ホスホグルコムターゼ phosphoglucomutase; 等電点電気泳動 isoelectric focusing

昭和 48〜 57 年までの 10 年間におけるフグ中毒患者は 714 名, 万ち死者は 200 名（致死率 $28 \%$ ） に達してい る ${ }^{1)}$. この死者数は同期間中の 食中毒による死者総数 (305 名) の約 2/3 を占める.

我が国におけるフグの需要は, 近年, 着実に増大し, 漁場の拡大もさることながら，輸入量も1981年には 646 トンにのぼっている．輸入フグのかなりの部分が東シナ 海産のもので占められるが，時にドクサバフグ Lagocephalus lunaris lunaris のような筋肉自体が有毒なもの

*1 東京大学農学部水産化学研究室：東京都文京区弥 生 1-1-1

*2 東京都市場衛生検査所：東京都中央区築地 5-2-1
が混入し，市場に流通して中毒事件も発生している22. また，ドクサバフグの干物がアンコウなどと偽って輸入 された事例もある ${ }^{3), 4)}$.

フグ中毒を防止するためには, その鑑別法の確立が急 務と考えられる.フグ類の鑑別は通常，外観，頭蓋骨の 形態などによっているが5 ，7)，皮を除去した“身欠き” や肉片では鑑別が不可能ないし困難である.

著者らは先に，魚種特異性が高いとされている筋肉の ミオゲン（水溶性タンパク質）画分に着目し，ドクサバ フグなど 3 種のサバフグ類を対象に，ポリアクリルアミ ドゲル電気泳動法によって, ミオゲン画分のタンパク質 やアイソザイムパターンを比較し，相互に鑑別できるこ とを報告した ${ }^{8)}$. 今回は対象をフグ類 16 種に拡大すると 
Table 1. Japanese and Scientific Names of the Puffer Specimens Used

\begin{tabular}{cll}
\hline \hline $\begin{array}{c}\text { Specimen } \\
\text { No. }\end{array}$ & Japanese name & \multicolumn{1}{c}{ Scientific name } \\
\hline 1 & Mafugu & Fugu vermicularis porphyreus \\
2 & Torafugu & F. rubripes rubripes \\
3 & Karasu & F. rubripes chinensis \\
4 & Higanfugu & F. pardalis \\
5 & Kusafugu & F. niphobles \\
6 & Shosaifugu & F. vermicularis vermicularis \\
7 & Komonfugu & F. poecilonotus \\
8 & Gomafugu & F. stictonotus \\
9 & Kurosabafugu & Lagocephalus subsp. \\
10 & Senninfugu & Pleuranacanthus sceleratus \\
11 & Mefugu & F. ocellatus obscrurus \\
12 & Takifugu & F. oblongus \\
13 & Shimafugu & F. xanthopterius \\
14 & Yoritofugu & F. bimaculatus \\
15 & Sansaifugu & Liosaccus cutaneus \\
16 & F. flavidus \\
\hline
\end{tabular}

* No Japanese name is available.

ともに，等電点電父泳動法等も導入して同様な検討を加 えたものである.

\section{試料及び方法}

試料

1983年夏から秋にかけて東京中央卸売市場で入手した 計16種のフグを供試した。それらの和名及び学名を Table 1 に示す.いずれも鮮魚あるいは貯蔵状態の良好 な凍結品であった，供試偑体数は各魚種につき，原則と して 1 個体とした.

\section{方法}

試料液の調製 以下の操作はとくに断わらない限り, 2〜40で実施した。背部から切り出した普通筋 $1 \mathrm{~g}$ に, 氷冷した $5 \mathrm{ml}$ の $0.05 M$ バルビタール緩衝液 $(\mathrm{pH}$ 8.6)ーグリセリン等容混液を加え，乳錸中で十分に磨砕 した．次いで， $3,000 \mathrm{rpm}, 10$ 分間の遠心分離に付し， 上清を得た。この上清に対し, 電気泳動用のマーカーと して $1 / 4$ 量の $0.001 \%$ の Bromophenol blue (BPB) を 加え，分析用試料とした。

ポリアクリルアミドゲル電気泳動 (PAGE) $\quad \mathrm{Akroyd}^{92}$ の方法に準じて行った．スラブゲルの厚さは $2 \mathrm{~mm}$ と し，また分離ゲル及び濃縮ゲルのアクリルアミド濃度は それぞれ，7.5\% 及び $3 \%$ とした。電解液には $5 \mathrm{mM}$ Tris-38 mM グリシン緩衝液（pH 8.3）を用い，濃縮ゲ ルでは $20 \mathrm{~mA}$, 分離ゲルでは $40 \mathrm{~mA}$ の定電流下, 通常 約 4 時間泳動を行った。泳動終了後, Coomassie brilliant blue R-250によりタンパク質染色を施した。 また，リンゴ酸脱水素酵素 $(\mathrm{MDH}$, E. C. 1. 1. 1 . 37) ${ }^{10)}$ ，ホスホグルコムターゼ (PGM, E. C. 2. 7. 5. 1. $)^{11)}$ ，及び乳酸脱水素酵素 $\left(\mathrm{LDH}\right.$, E. C. 1. 1. 1. 27) ${ }^{12)}$
の各活性染巴をも試みた.

セルロースアセ テート膜電気泳動 (CAME) 小川13) の方法に準じて行った。膜には Separax（フジフィル ム) を, 電解液には $0.05 M$ バルビタール緩衝液 $(\mathrm{pH}$ 8.6)を用い, $0.4 \mathrm{~mA} / \mathrm{cm}$ の定電流下，室温で50分間泳 動した. 泳動終了後, Ponceau $3 \mathrm{R}$ でタンパク質を染色 した.

等電点電気泳動 (IEF) $3 \%$ の Ampholine (LKB, $\mathrm{pH} 3.5 \sim 10)$ を含む $5 \%$ アクリルアミドの薄層ゲル（厚 さ $0.5 \mathrm{~mm}$ )を用いた．電解液には $1 M$ リン酸 (陽極) 及 び $0.1 N$ 水酸化ナトリウム液溶 (陰極) を用い, $1,500 \mathrm{~W}$ の定電力下， $10^{\circ} に て 90$ 分間泳動を行った。泳動終了後， 表面電極を用いてゲル表面の $\mathrm{pH}$ を测定した．次いで， $3.5 \%$ スルホサリチル酸 $-12 \%$ トリクロル酢酸で固定後, Coomassie brilliant blue R-250によりタンパク質を染 色した.

\section{結果及び考察}

PAGE における 16 種のフグのタンパク質の泳動パタ ーンをFig. 1 に示寸. 全魚種を通じ, Rm (BPB の移動 距離を 1 としたときの相対易動度） 0.3 前後の濃厚なバ ンドが見られたが，七ンニンフグ（No. 10）の当該バン ドの $\mathrm{Rm}$ 值は他魚種に比べ，明らかに小さかった， $\mathrm{Rm}$ $0.4 \sim 0.8$ の数本のバンドには顕著な種特異性がみられ, フグ類相互の鑑別上，有用と認められた。 また， $\mathrm{Rm}$ 0.2 付近のバンドにも若干の種特異性が㤠められた. ただし，トラフグ (No. 2) とカラス (No. 3) の場 合，またショウサイフグ (No. 6) とコモンフグ (No. 7) の場合には，少なくとも定性的にはパターンには差がみ られず，判別は困難と認められた. メフグ (No. 11)，タ 
Specimen No.
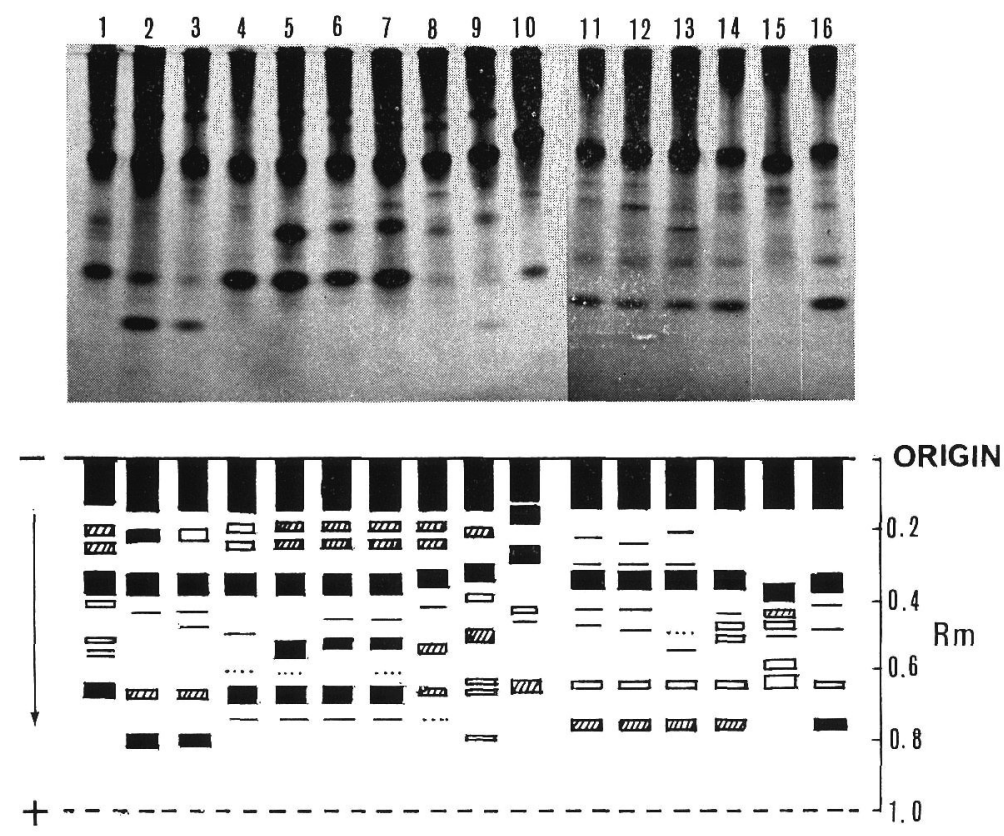

Fig. 1. Polyacrylamide gel electrophoresis of the myogen fractions prepared from the ordinary muscle of puffers

Coomassie brilliant blue staining. $7.5 \%$ gel.

Refer to Table 1 for the specimens No. 1-16.

Specimen No.
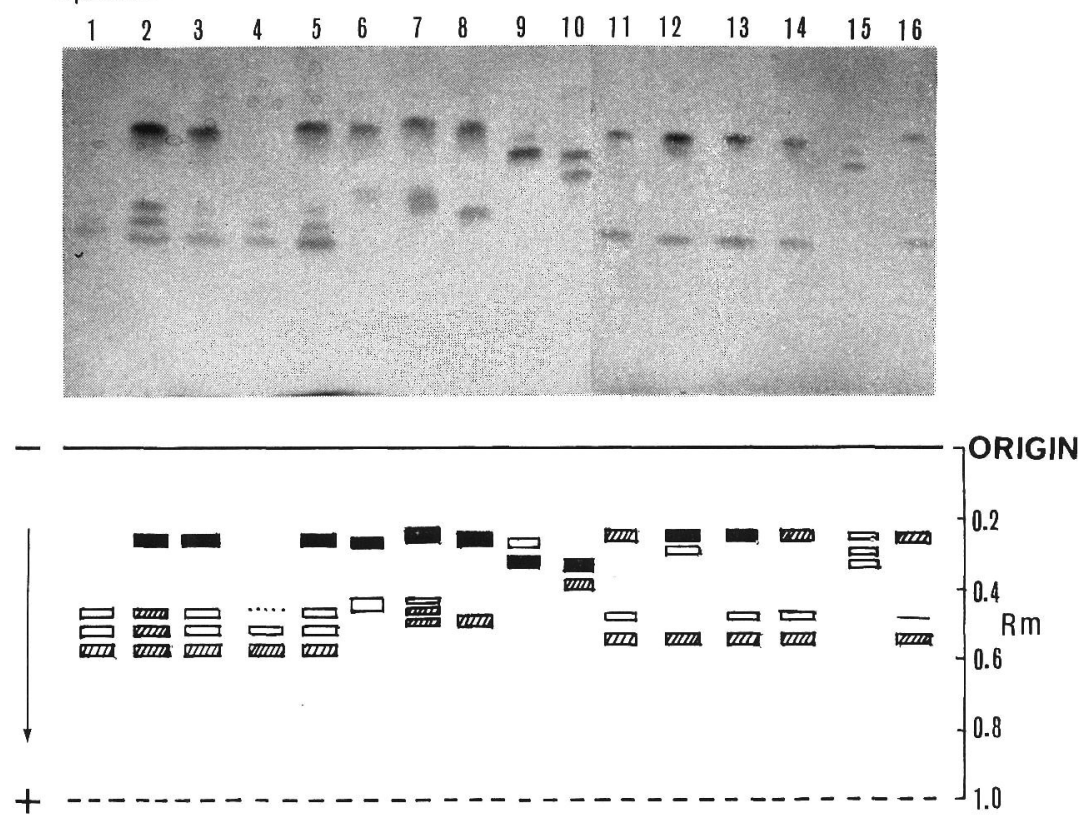

Fig. 2. Isozyme patterns of malate dehydrogenase from the ordinary muscle of puffers on $7.5 \%$ polyacrylamide gel

Refer to Table 1 for the specimens No. 1-16. 
Specimen No.
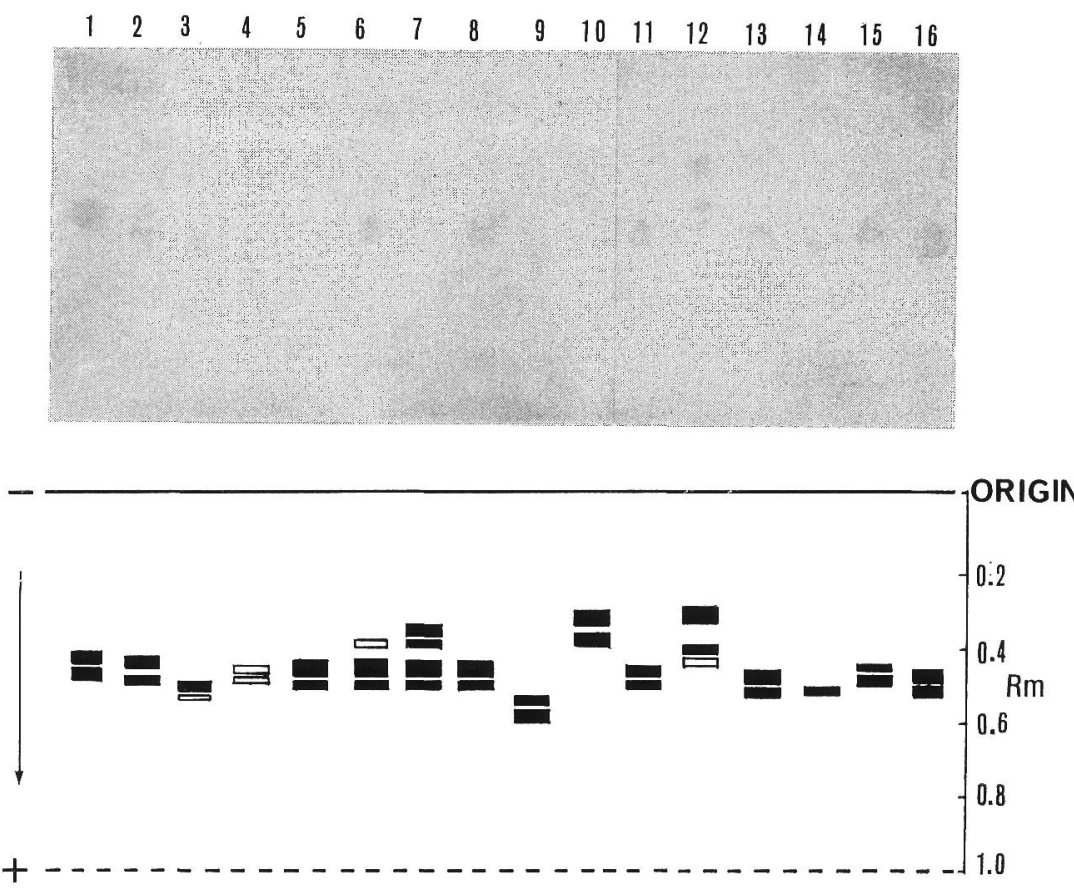

Fig. 3. Isozyme patterns of phosphoglucomutase from the ordinary muscle of puffers on $7.5 \%$ polyacrylamide gel Refer to Table 1 for the specimens No. 1-16.

\section{Specimen No.}

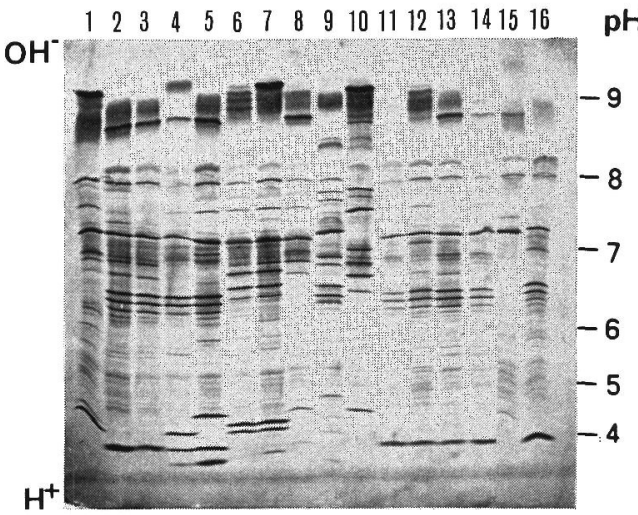

Fig. 4. Isoelectric focusing of the myogen fractions prepared from the ordinary muscle of puffers

Coomassie brilliant blue staining

Refer to Table 1 for the specimens No. $1-16$.

キフグ (No. 12)，シマフダ (No. 13)，F. bimaculatus (No. 14)，サンサイフグ（No. 16）ではパターンがかな
り似るが， $\mathrm{Rm} 0.2$ 付近及び $0.4 \sim 0.8$ の数本のバンド そより，相互の鑑別は一応可能であった。

次に, Fig. 2 沉示すように, MDH のアイソザイムパ ターンについても，かなりの種特異性が認められた、マ フグ (No. 1) 及びヒガンフグ (No. 4) の相互間, トラ フグ (No. 2)，カラス (No. 3) 及びクサフグ (No. 5) の3者間，あるいはメフグ (No. 11)，タキフグ（No. 12), シマフグ (No. 13)，F. bimaculatus (No. 14)及び サンサイフグ (No. 16) の5者間では，それ灻れパター ンがよく似ていた。クロサバグ (No. 9)，センニンフ グ (No. 10)，ヨリトフグ (No. 15) では，それぞれに特 徽的なパターンが見られた。また，前記のタンパク質パ ターンでは相互鑑別が難しかったショウサイフグ（No. 6）とコモンフグ（No. 7）毛明確に判別できた。

PGM のアイソザイムパターン (Fig. 3) は, 各魚種之 もバンド数は少ないものの有意の種特異性を示し，之く にトラフグ（No. 2) とカラス (No. 3) で明確な相違が 認められた.ショウサイフグ (No. 6) とコモンフダ (No. 7）の判別字容易であった。

LDH のアイソザイムパターンについても検討したが, $\operatorname{Rm} 0.2$ 付近の 1 本のバンドしか認められない場合が多 く, フグ類の鑑別への応用は不適当と考光られた。 
CAMEにおケるミオゲンのパターンについては，各 魚種で 1〜3 本の， Rm が接近したバンドが認められた のみで，本法によるフグ類の鑑別は困難であった.

次に, Fig. 4 に示すように, IEF では PAGE や CAMEに比べて，はるかに多数の，かつシャープなバ ンドが得られ，魚種相互間の鑑別は総じて容易であっ た. トラフグ (No. 2) とカラス (No. 3) についても, $\mathrm{pH} 7 \sim 8$ のバンドの有無に沶いて明確な差が見られ，本 法が近縁種や雑種などの鑑定に有用であることを示㖫し た.

最後に補足的ながら，個体差の有無につき，ヒガンフ グ（20個体）及びョリトフグ（4 個体）の婀魚種を用い て，若干の検討を行った，図は省略するが，まずヒガン フグの場合には, PAGEにおけるタンパク質パターン (Fig. 1, No. 4 参照) 中, Rm 0.50 のバンドのほか, 試料によっては，その前後に弱い数本のバンドを示すな どの個体差がみられたが，鑑別に支障をきたすほどでは なかった. MDH やPGM のアイソザイムパターンに関 しては，個体差が全く認められなかった。他方，ヨリト フグについても，IEF を含む全電気泳動に打いて，個体 差は全くみられなかった.

以上の諸結果から，フグ類の鑑別には，CAMEを除 く前記の諸種の電気泳動法によるタンパク質やアイソザ イムパターンの分析が有用であること，それらの方法の 併用はさらに鑑定の確実度を増すことなどが示された。

谷口 ${ }^{14)}$ はデンプンゲル電気泳動法によって数種のフク のミオゲン画分のタンパク質パターンを調べ，種特異的 なことをみた。また，ごく最近，増田ら*1はフグ雑種の 遺伝的研究の中で，諸種のフグ類につき，同じ技法でタ ンパク質パターンなどの比較を試みている．本研究で用 いた IEF は分離能においてょり優れており，ここに供 試した16魚種の鑑別も一応可能なことが示された。しか し，アクリルアミドを支持体とするこれらの電気泳動に おいては，泳動パターンはゲルのでき具合等の関係で完 全に再現性があるとはい方ず，常に既知試料を同時に泳 動にかけることが望ましい.

今後, これらの方法のより一層の改善をはかるととも に，干物など加工品の鑑別法についても検討する予定で ある。

要 約

16種のフグにつき，普通筋のミオゲン画分の電父泳動
分析による相互鑑別の可能性を調べた.

ポリアクリルアミドゲル電気泳動におけるタンパク質 パターンは総じて顕著な種特異性を示し，一部のものを 除き，相互鑑別が可能であった，MDH や PGM のパタ ーンにも有意の種特異性が認められ，タンパク質パター ンとの併用は，鑑別をより確実にするものと考兄られ た.

他方，等電点電気泳動におけるタンパク質パターン は, 検出バンド数も多く, 著しく種特異的で, 近縁種等 の鑑別上，有用と涩められた。

謝辞

本研究の実施にあたり，供試フグの同定をして頂いた 東京大学総合研究資料館 阿部宗明博士に深謝する。な お，本研究費の一部は，厚生科学研究貿補助金により支 升した。ここに記して謝意を表する。

\section{文献}

1）田口博人：食品衛生研究，34，113～137（1984）。

2) 多部田 修: 同上. 33，565５75 (1983).

3）原田祜影，时原迫洋一：同上. $31,313 \sim 318$ (1981) .

4）河端俊治，戸円敦夫，松本恵子，原时祯顕：同 上. $31,827 \sim 837$ (1981).

5）古沢陽一：同上. 21, 144 147 (1971).

6）四口博人：同上. 32，1049～1066（1982）。

7）原田禎顕：食衛誌。20，437４41（1979）。

8）橋本周久, 渡部終五, 中川孝之, 反田健児：日水 誌. 50, 115 118 (1984)

9) Akroyd, P.: Anal. Biochem. 19, 399 410 (1967)

10) Rotmans, J. P.: Exptl. Parasitol. 46, 31 48 (1978)

11) Spencer, N., Hopkinson, D. A., Harris, H.: Nature. 204, 742 745 (1964).

12) Shaw, C. R., Prasad, R.: Biochem. Genet. 4, 297 320 (1970).

13）小川恕人：臨床病理，臨時增刊 11 皆。 46 66 (1970).

14）谷口順浐：高知大学水産実験所報告第 1 号。 p. 145 (1974).

*1 增田育司, 竹剛品一郎, 多部田 修: 昭和 59 年 度日本水産学会春季大会講演要旨集, p. 110 (1984). 